\title{
Natural Diet of Juvenile Abalone Haliotis fulgens and $H$. corrugata (Mollusca: Gastropoda) in Bahía Tortugas, Mexico ${ }^{1}$
}

\author{
Sergio A. Guzmán del Próo, ${ }^{2}$ Elisa Serviere-Zaragoza, ${ }^{3,4}$ and David Siqueiros-Beltrones ${ }^{5}$
}

\begin{abstract}
Diet of juvenile (10-100 $\mathrm{mm}$ in length) abalone (Haliotis fulgens and $H$. corrugata) in their natural environment was examined in specimens collected at Bahía Tortugas, Baja California Sur. Nine macroalgae species, one polychaete worm, one amphipod, one hydrozoan, and one sea grass were identified. A high percentage of stomachs analyzed were empty. In those with contents, Pbyllospadix torreyi (Anthophyta), Laurencia sp., Gelidiales (Rhodophyta), and Phaeophyta (Dictyotales) were the most common items. Most specimens with macroalgal material came from depths in which $H$. fulgens (shallow) and $H$. corrugata $(>6 \mathrm{~m}$ ) are more abundant. Benthic diatoms were almost absent from ingested material.
\end{abstract}

Most literature on natural abalone diet is based on analysis of stomach contents of adults, and information on the diet of small juveniles is sparse (e.g., Tomita and Tazawa 1971, Shepherd and Cannon 1988, Wood and Buxton 1996). Kawamura et al. (1998) reviewed the available information on the feeding habits and growth of abalone postlarvae and early juveniles $(5-10 \mathrm{~mm})$ and concluded that most of their diet consists of diatoms, bacterial films, and sporelings of macroalgae.

In the wild, adult abalone feed on the three main groups of macroalgae: brown, red, and

\footnotetext{
1 This study was partially financed by IPN-Coordinación General de Estudios de Posgrado e Investigación (project 200494), (CONACYT project (047PN1297) and CIBNOR (project PAC8). S.A.G.P. was partly supported by CIBNOR during his sabbatical stay, of which part was used to work on this investigation. S.A.G.P. and D.S.-B. are fellows of the Comision de Fomento de Actividades Académicas (COFAA).

${ }^{2}$ Escuela Nacional de Ciencias Biológicas, Instituto Politécnico Nacional (IPN). Prolongación de Carpio y Plan de Ayala s/n, México, D.F. 11340, México.

3 Corresponding author.

${ }^{4}$ Centro de Investigaciones Biológicas del Noroeste (CIBNOR), P.O. Box 128, La Paz, B.C.S., 23000, México (E-mail: serviere@cibnor.mx).

${ }^{5}$ Centro Interdisciplinario de Ciencias Marinas (CICIMAR-IPN). P.O. Box 592, La Paz, B.C.S., 23000, México.
}

Pacific Science (2003), vol. 57, no. 3:319-324

(C) 2003 by University of Hawai'i Press

All rights reserved green, albeit in different proportions (Fallu 1991, Shepherd and Steinberg 1992). Species of Macrocystis, Egregia, and other Laminariales have been used commonly as fodder in abalone farms (Cook 1998, Godoy and Jérez 1998, McBride 1998).

Information on natural diet and feeding habits of abalone species found along Mexican coasts is scarce. Serviere-Zaragoza et al. (1998) analyzed the stomach contents of $\mathrm{Hal}$ iotis fulgens Philippi, 1845, adults, sampled at their southern distributional limit. Several species of macroalgae, including Eisenia arborea Areschoug, 1876, Sargassum sp., Cryptopleura crispa Kylin, 1924, and Rbodymenia sp., and the sea grass Pbyllospadix torreyi S. Watson were the most common species in the diet. Siqueiros-Beltrones et al. (2001, 2002) provided an inventory of the epiphytic diatoms found on the blades of macroalgae used to feed cultured abalone, such as Macrocystis pyrifera (Linnaeus) C. Agardh, 1820, and Eisenia arborea.

A recent study (Carreón-Palau 2000) on microhabitat and abundance of Haliotis fulgens and $H$. corrugata Wood, 1828 , juveniles, in the central region of Baja California, recorded 42 species of flora on the rocks where Haliotis spp. might feed. In this study, we describe the feeding spectrum of juvenile $H$. fulgens and $H$. corrugata collected from the sampling sites of the Carreón-Palau (2000) study. This information will be used to support emerging aquacultural projects in this region. 


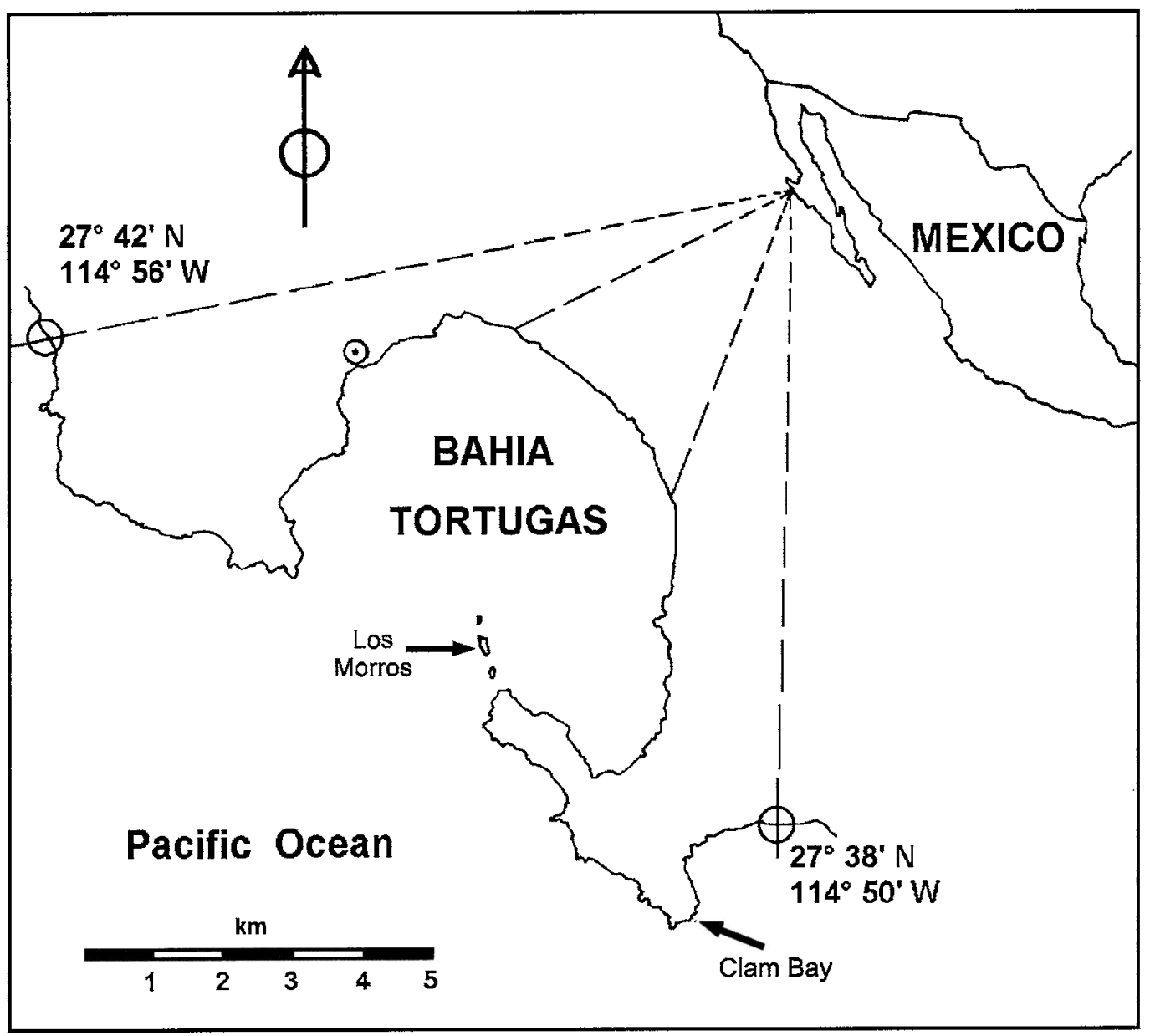

Figure 1. The two study sites, Clam Bay and Los Morros, in Baja California Sur, Mexico.

\section{MATERIALS AND METHODS}

Specimens of Haliotis fulgens and $H$. corrugata were collected on two reefs: Clam Bay and Los Morros (Figure 1). Sampling was carried out during different seasons at depths that followed the reef profile: 1,3 , and $5 \mathrm{~m}$ at Clam Bay and 6, 9, and $12 \mathrm{~m}$ at Los Morros.

In the laboratory, specimens were dissected and gut and stomach contents were extracted under a stereoscope and preserved in $70 \%$ alcohol. Identification of ingested material was based on external morphology and internal anatomy of macroalgae fragments. Identification keys for genera and species of macroalgae included Joly (1967) and Abbott and Hollenberg (1976). In some cases, internal anatomy of fresh macroalgae species collected from each site was used to confirm our identifications. In addition, a subsample from each sample was used for observations of diatoms.

The relative frequency (RF) of each species was calculated as: $\mathrm{RF}=$ (frequency value for a species/total of the frequency values for all species) $\times 100$. 
TABLE 1

Number of Specimens of Haliotis fulgens (Hf) and $H$. corrugata (Hc) Juveniles Collected in Bahía Tortugas, Baja California Sur, Mexico

\begin{tabular}{lccccc}
\hline & Nov. & Apr. & Nov. & Apr. & Jan. \\
Study Site & 1996 & 1997 & 1997 & 1998 & 2002 \\
\hline Clam Bay & 9 (Hf) & 8 (Hf) & 3 (Hf) & 9 (Hf) & 2 (Hf) \\
Los Morros & 6 (Hf) & 5 (Hf) & 6 (Hf) & 2 (Hf) & 10 (Hc) \\
\hline
\end{tabular}

TABLE 2

Percentage of Juvenile Haliotis fulgens in Clam Bay and Los Morros with Ingested Material or Empty Stomachs (Parentheses Indicate Percentages of All Samples)

\begin{tabular}{|c|c|c|c|}
\hline \multirow[b]{2}{*}{ Condition } & \multicolumn{2}{|c|}{ Clam Bay } & \multirow{2}{*}{$\begin{array}{c}\begin{array}{c}\text { Los } \\
\text { Morros }\end{array} \\
6-12 \mathrm{~m}\end{array}$} \\
\hline & $\leq 1 \mathrm{~m}$ & $1-5 \mathrm{~m}$ & \\
\hline With contents & $86(27)$ & $50(13)$ & $10(4)$ \\
\hline Stomach empty & $14(5)$ & $50(13)$ & $90(38)$ \\
\hline
\end{tabular}

RESULTS

For the entire study, a total of 50 juvenile $H$. fulgens and 10 juvenile $H$. corrugata was collected from the two sites. Shell length ranged from 10 to $100 \mathrm{~mm}$. The numbers collected during each season and at different depths varied (Table 1).

\section{Haliotis fulgens}

From Clam Bay, 31 specimens with a mean size of $47.4 \pm 22.5 \mathrm{~mm}$ (SD) and, from Los Morros, 19 specimens with a mean size of $48.4 \pm 26.0 \mathrm{~mm}(\mathrm{SD})$ were analyzed. Overall, at both localities, a high proportion of specimens had empty stomachs (56\%) (Table 2 ). Most of the samples containing macroalgae were small fragments. The number of algal species varied from one to three, but most commonly only one species was found.

Fragments of 13 species were identified, of which nine corresponded to macroalgae, one to a sea grass, one to a hydrozoan, one to a polychaete, and one to an amphipod (Table 3). Most taxa appeared during a single season, except for Phyllospadix torreyi, which was present during both years in autumn and spring. This species also had the highest relative frequency, followed by the Gelidiales group, which occurred during spring and summer 1997 (Table 3).

Most macroalgae were found in juveniles from $1 \mathrm{~m}$, with the exception of $P$. torreyi, which occurred in specimens collected at 1,3, and $5 \mathrm{~m}$ (Table 3 ). Diatoms were absent from stomach contents.

\section{Haliotis corrugata}

In Los Morros, the mean size of juveniles was $48.4 \pm 10.8 \mathrm{~mm}$ (SD). Most samples originated at 9 and $12 \mathrm{~m}$. Traces of ingested material were found in $70 \%$ of the stomachs and included four phaeophytes, two rhodophytes, and several cyanophytes (Table 3). Only one or two species were found in each stomach. Diatoms were almost absent from stomach contents. Only a couple of frustules, probably Cocconeis cf. dirupta Gregory, were present within the stomachs.

\section{DIsCUSSION}

Most of the algae found in the stomachs of $H$. fulgens and $H$. corrugata form part of the algal community recorded in earlier work on the microhabitat occupied by juveniles (CarreónPalau 2000). In this microhabitat, the dominant macroalgae were crustose corallines and articulated forms. Also common were rhodophytes, such as Cbondracantbus canaliculatus (Harvey) Guiry, 1993, Hypnea valentiae (Turner) Montagne, 1841, and Gelidium pusillum (Stackhouse) Le Jolis, 1863. Sea grass $P$. torreyi was recorded as a dominant species during certain seasons.

Although $P$. torreyi and Gelidiales were the most frequent components found in most of the specimens studied, we cannot determine preferences without demonstrating if the proportions of species in the gut differ significantly from the proportions available in the microhabitat. Leighton (2000) suggested that Pbyllospadix and Gelidiales are ingested incidentally. However, the frequent presence of Pbyllospadix spp. in juvenile stomachs in this and a previous study of adult $H$. fulgens 
TABLE 3

Identified Taxa in the Stomach Contents of Juvenile Haliotis fulgens and $H$. corrrugata

\begin{tabular}{|c|c|c|c|c|c|}
\hline Haliotis sp. & Taxon & Locality ${ }^{a}$ & Season $^{b}$ & Depth $(\mathrm{m})$ & $\begin{array}{c}\text { Relative } \\
\text { Frequency } \\
(\%)\end{array}$ \\
\hline \multicolumn{6}{|l|}{ H. fulgens } \\
\hline & \multicolumn{5}{|l|}{ Chlorophyta } \\
\hline & Cladopbora sp. & 1 & 3 & 1 & 3 \\
\hline & Cbaetomorpha sp. & 1 & 3 & 1 & 3 \\
\hline & \multicolumn{5}{|l|}{ Phaeophyta } \\
\hline & Colpomenia sp. & 1 & 3 & 1 & 3 \\
\hline & Dictyota sp. & 1 & 4 & 1 & 6 \\
\hline & Phaeophyte sp. 1 & 1 & 2 & 1 & 3 \\
\hline & Phaeophyte sp. 2 & 1 & 3 & - & 3 \\
\hline & \multicolumn{5}{|l|}{ Rhodophyta } \\
\hline & Laurencia sp. & 1 & 4 & 1 & 6 \\
\hline & Gelidiales & 1 & 2,3 & 1 & 13 \\
\hline & Rhodophyte sp. 1 & 2 & 1 & 6 & 3 \\
\hline & \multicolumn{5}{|l|}{ Anthophyta } \\
\hline & Pbyllospadix torreyi & 1 & $1-5$ & $1,3,5$ & 47 \\
\hline & Hydrozoa & 1 & 1 & 3 & 3 \\
\hline & Polychaete & 2 & - & 12 & 3 \\
\hline & Amphipod & 2 & - & 12 & 3 \\
\hline & Total & & & & 100 \\
\hline \multirow{2}{*}{\multicolumn{6}{|c|}{ H. corrugata }} \\
\hline & & & & & \\
\hline & Dictyota sp. & 2 & \multicolumn{2}{|c|}{ Phaeophyta } & 20 \\
\hline & Phaeophyte sp. 3 & 2 & 5 & 12 & 10 \\
\hline & Phaeophyte sp. 4 & 2 & 5 & 12 & 10 \\
\hline & Phaeophyte sp. 5 & 2 & 5 & 12 & 10 \\
\hline & \multicolumn{5}{|l|}{ Rhodophyta } \\
\hline & Gelidiales & 2 & 5 & 12 & 20 \\
\hline & Rhodophyte sp. 2 & 2 & 5 & 9 & 20 \\
\hline & Cyanophyta & 2 & 5 & 9 & 10 \\
\hline & Total & & & & 100 \\
\hline
\end{tabular}

a 1, Clam Bay; 2, Los Morros.

b 1, November 1996; 2, April 1997; 3, November 1997; 4, April 1998; 5, January 2002.

(Serviere-Zaragoza et al. 1998) suggests that Pbyllospadix, rather than being incidental, is part of the green abalone diet, at least in the populations of Baja California Sur. Recent laboratory studies on growth of juvenile $H$. fulgens fed Pbyllospadix torreyi, Eisenia arborea, or Gelidium robustum (N. L. Gardner) Hollenberg \& I. A. Abbott, 1965, showed that these species were acceptable food and did not lead to significant differences in growth (Serviere-Zaragoza et al. 2001). Tomita and Tazawa (1971) also showed that macroalgae and sea grasses dominated the diet of juvenile (10 to $20 \mathrm{~mm}) H$. discus bannai Ino, 1953.
Regarding diatom components of the diet, only scarce specimens of Cocconeis cf. dirupta were observed in one $H$. corrugata stomach. A partial explanation for low occurrence is that the average shell length $(48 \mathrm{~mm})$ of the juvenile abalone was greater than the size $(5-10$ $\mathrm{mm})$ at which diatoms have been reported as an important part of juvenile and postlarval diet (Tomita and Tazawa 1971, Shepherd and Cannon 1988, Kawamura et al. 1998). Leighton (2000) indicated that in younger stages, abalone graze on particulate organic matter and microphytobenthos plankton, including diatoms. In other studies, however, 
abalone larger than $50 \mathrm{~mm}$ from Isla Magdalena, $400 \mathrm{~km}$ south of Bahía Tortugas, had abundant diatoms in their guts (SiqueirosBeltrones 2000, Siqueiros-Beltrones and Valenzuela-Romero 2001). All were epiphytic forms from both crustose and articulated corallines, as well as fleshy macroalgae.

\section{ACKNOWLEDGMENTS}

We thank Jorge Belmar, Alejandro Villa, Laura Carreón, Raúl Herrera, and Jorge Carrillo for collecting specimens. Sociedad Cooperativa de Producción Pesquera Bahía Tortugas provided logistical support during the fieldwork, and the Instituto Nacional de la Pesca allowed use of their Bahía Tortugas facilities. We are grateful to Scoresby Shepherd and anonymous reviewers for their valuable suggestions. Thanks also to the editing staff at CIBNOR for corrections and comments.

\section{Literature Cited}

Abbott, I. A., and J. N. Hollenberg. 1976. Marine algae of California. Stanford University Press, Stanford, California.

Carreón-Palau, L. 2000. Microhábitat, distribución y abundancia de juveniles de abulón, Haliotis fulgens y $H$. corrugata en Bahía Tortugas, B.C.S., México. M.S. thesis, Escuela Nacional de Ciencias Biológicas-Instituto Politécnico Nacional, México.

Cook, P. 1998. The current status of abalone farming in South America. J. Shellfish Res. 17 (3): 601-602.

Fallu, R. 1991. Abalone farming. Fishing News Books, Oxford.

Godoy, C., and G. Jérez. 1998. The introduction of abalone in Chile: Ten years later. J. Shellfish Res. 17 (3): 603-606.

Joly, A. B. 1967. Géneros de algas marinhas da costa Atlántica, Latinoamérica. Editora da USP, São Paulo, Brazil.

Kawamura, T., D. R. Roberts, and H. Takami. 1998. A review of the feeding and growth of postlarval abalone. J. Shellfish Res. 17 (3): 615-626.

Leighton, D. L. 2000. The biology and cul- ture of the California abalones. Dorrance Publishing Co., Pittsburgh, Pennsylvania.

McBride, S. C. 1998. Current status of abalone aquaculture in the Californias. J. Shellfish Res. 17 (3): 593-600.

Serviere-Zaragoza, E., D. Gómez-López, and G. Ponce-Díaz. 1998. The natural diet of the green abalone (Haliotis fulgens Philippi) in the southern part of its range, Baja California Sur, Mexico, assessed by an analysis of gut contents. J. Shellfish Res. 17 (3): $777-782$.

Serviere-Zaragoza, E., A. Mazariegos-Villarreal, G. Ponce-Díaz, and S. Montes-Magallón. 2001. Growth of juvenile abalone, Haliotis fulgens Philippi fed different diets. J. Shellfish Res. 20 (2): 689-694.

Shepherd, S. A., and J. Cannon. 1988. Studies on southern Australian abalone (genus Haliotis). X. Food and feeding of juveniles. J. Malacol. Soc. Aust. 9:21-26.

Shepherd, S. A., and P. D. Steinberg. 1992. Food preferences of three Australian abalone species with a review of the algal food of abalone. Pages 169-181 in S. A. Shepherd, M. J. Tegner, and S. A. Guzmán del Próo, eds. Abalone of the world: Biology, fisheries and culture. Fishing News Books, Oxford.

Siqueiros-Beltrones, D. A. 2000. Benthic diatoms associated to abalone Haliotis spp. on a rocky substratum from Isla Magdalena, Baja California Sur, México. Oceanides 15 (1): 35-46.

Siqueiros-Beltrones, D. A., and G. Valenzuela-Romero. 2001. New records of benthic diatoms from natural grazing surfaces of abalone (Haliotis spp.) habitats in the Baja California peninsula. Oceanides 16 (2): 107-126.

Siqueiros-Beltrones, D. A., E. Serviere-Zaragoza, and U. Argumedo-Hernández. 2001. First record of the diatom Cocconeis notata Petit living inside the hydrotheca of a hydrozoan epiphyte of Macrocystis pyrifera (L.) C. Ag. Oceanides 16 (2): $135-$ 138.

2002. Epiphytic diatoms of Macrocystis pyrifera (L.) C. Ag. from the Baja California peninsula, México. Oceanides 17 (1): 31-39. 
Tomita, K., and N. Tazawa. 1971. On the stomach contents of juveniles abalone Haliotis discus bannai Ino, in Rebun Island, Hokkaido. Sci. Rep. Hokkaido Fish. Exp. Stn. 13:31-38 (in Japanese with English abstract).
Wood, A. D., and C. D. Buxton. 1996. Aspects of the biology of the abalone Haliotis midae (Linne, 1758) on the east coast of South Africa. 1. Feeding biology. S. Afr. J. Mar. Sci./S. Afr. Tydskr. Seewetenskap $17: 61-68$. 